\title{
Pengaruh Persepsi Mahasiswa Tentang Status Sosial Guru Dan Pendidikan Profesi Guru (PPG) Terhadap Motivasi Menjadi Guru Sekolah Dasar
}

\author{
Dyah Indraswati1, Prihma Sinta Utami2 ${ }^{2}$, Suyitno ${ }^{3}$, Dodik Kariadi ${ }^{4}$ \\ 1dyahindraswati@unram.ac.id, 2prihmasinta@gmail.com, 33suyitno@pgsd.uad.ac.id, \\ ${ }^{4}$ kariadidodik@gmail.com \\ 1 Universitas Mataram, ${ }^{2}$ Universitas Muhammadiyah Ponorogo, ${ }^{3}$ Universitas Ahmad Dahlan, \\ 4STIKIP Singkawang
}

DOI. 10.18860/mad.v12i2.8963

Abstract. This study aims to determine: (1) the effect of students' perceptions of the teacher's sosial status on student motivation to become a primary teachers; (2) the effect of students' perceptions about teacher professional education programs (PPG) on student motivation to become a primary teachers; (3) the effect of students' perceptions about the sosial status of teachers and teacher professional education programs (PPG) on student motivation to become a primary teachers. This research is an ex post facto research with a quantitative approach. The subjects in this study were the 7th-semester students of the University of Mataram's PGSD study program, amounting to 315, then samples were taken using the Slovin formula so that 177 students were obtained. The data collection method uses a questionnaire. Data analysis uses descriptive statistical analysis; analysis prerequisite test consisting of normality test, linearity test, and multicollinearity test; and regression analysis consisting of a simple linear regression test and multiple linear regression test. The results showed: (1) There was a positive and significant influence of students' perceptions about the teacher's sosial status on motivation to become a teacher. (2) There is a positive and significant influence of students' perceptions about PPG on motivation to become a teacher. (3) There is a positive and significant influence of students' perceptions about the sosial status of teachers and PPG simultaneously on the motivation of students to become teachers.

Keywords. Student Perception; Teacher's Sosial Status; PPG; Motivation to Become A Teacher.

\begin{abstract}
Abstrak. Tujuan dari penelitian ini adalah mengetahui: (1) pengaruh persepsi mahasiswa tentang status sosial guru terhadap motivasi mahasiswa menjadi guru Sekolah Dasar; (2) pengaruh persepsi mahasiswa tentang program Pendidikan Profesi Guru (PPG) terhadap motivasi mahasiswa menjadi guru Sekolah Dasar; (3) pengaruh persepsi mahasiswa tentang status sosial guru dan program Pendidikan Profesi Guru (PPG) terhadap motivasi mahasiswa menjadi guru Sekolah Dasar. Penelitian ini merupakan penelitian expost facto dengan pendekatan kuantitatif. Subjek penelitian mahasiswa semester 7 prodi PGSD Universitas Mataram yang berjumlah 315, kemudian diambil sample sebanyak 177 mahasiswa menggunakan rumus Slovin. Pengumpulan data menggunakan kuesioner. Data dianalisis dengan analisis statistik deskriptif dan uji prasyarat yang terdiri dari uji normalitas, uji linearitas, uji multikolinearitas; dan analisis regresi yang terdiri dari uji regresi linear sederhana dan uji regresi linear ganda. Hasil penelitian: (1) Terdapat pengaruh positif dan signifikan persepsi mahasiswa tentang status sosial guru terhadap motivasi mahasiswa menjadi guru SD. (2) Terdapat pengaruh positif dan signifikan persepsi mahasiswa tentang program Pendidikan Profesi Guru (PPG) terhadap motivasi mahasiswa menjadi guru SD. (3) Terdapat pengaruh positif dan signifikan persepsi mahasiswa tentang status sosial guru dan program Pendidikan Profesi Guru (PPG) secara simultan terhadap motivasi mahasiswa menjadi guru SD.
\end{abstract}

Kata Kunci. Persepsi Mahasiswa; Status Sosial Guru; PPG; Motivasi Menjadi Guru.

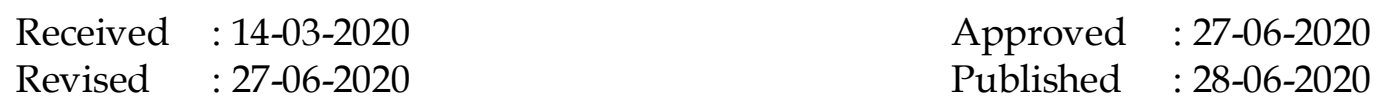




\section{MADRASAH}

Jurnal Pendidikan dan Pembelajaran Dasar

p ISSN: 1979-5599 | e ISSN: 2502-194X

P a g e

Copyright $@$ Madrasah Jurnal Pendidikan dan Pembelajaran Dasar. All Right Reserved.

This is an open access article under the CC BY-NC-ND license

(http:/ / creativecommons.org/licenses/by-nc-nd/4.0/).

Correspondence Address: dyahindraswati@unram.ac.id

\section{A. PENDAHULUAN}

Guru masih menjadi profesi yang banyak diminati sekaligus mendapat perhatian khusus dari pemerintah. Guru memiliki peran penting dalam mengelola proses pendidikan (I Ketut Margi, 2013). UU RI Nomor 14 Tahun 2005, Bab I Pasal 1 ayat (1) menyebut guru merupakan pendidik profesional dengan tugas utama membimbing, mendidik, melatih, mengarahkan, mengajar, menilai, serta melakukan evaluasi pada peserta didik jalur pendidikan dasar dan menengah. Pendidik profesional harus memiliki kualifikasi akademik dan kompetensi sebagai agen perubahan (Dantes, 2007). Agar menjadi profesional perlu adanya pola pembinaan karir secara tersistem (Ridho, 2014). Pada Bab IV Pasal 10 ayat (1) disebutkan kompetensi guru meliputi kompetensi pedagogic, kompetensi kepribadian, kompetensi sosial, dan kompetensi profesional yang diperoleh melalui pendidikan profesi. Pendidikan membantu mengaktualisasikan potensi menjadi kemampuan yang bermanfaat. Fungsi pendidikan antara lain pemahaman sosial, kecakapan sosial, dan sikap sosial (Widodo, Indraswati, \& Sobri, 2019). Permendikbud nomor 87 Tahun 2013, pasal 1 ayat (2) menyebut Program Pendidikan Profesi Guru Prajabatan (PPG) merupakan program yang dilaksanakan sebagai upaya menyiapkan lulusan S1 Kependidikan dan S1/DIV Nonkependidikan yang memiliki minat menjadi guru agar menguasai kompetensi guru secara utuh sesuai dengan standar nasional pendidikan dan memperoleh sertifikat pendidik profesional. Guru profesional adalah guru yang ahli dibidangnya, memiliki landasan pengetahuan, kompetensi, kesadaran profesional, kode etik, dan organisasi profesi. (Sutisna, Indraswati, \& Sobri, 2019). Program PPG penting karena mempengaruhi kinerja guru yang secara jangka panjang berpengaruh terhadap kelangsungan seluruh proses pembelajaran di dalam kelas dan akhirnya berpengaruh pada kualitas lulusan. (Werang, 2010).

Motivasi menjadi guru adalah segala sesuatu yang menjadikan mahasiswa bersemangat dan berkeinginan untuk menjadi guru. Motivasi bisa muncul dari dalam maupun dari luar diri mahasiswa. Mahasiswa sebagai agen perubahan perlu memiliki kompetensi dan wawasan yang luas (Widodo, A., dkk 2020). Wawasan yang luas membuat mahasiswa dapat menciptakan ide kreatif dalam membangun peradaban bangsa (Widodo, Husniati, Indraswati, Rahmatih, \& Novitasari, 2020). Penelitian yang dilakukan oleh Muhammad Sugiharto tahun 2018 menunjukkan hasil persepsi mahasiswa tentang profesi guru dan program PPG memiliki pengaruh positif dan signifikan terhadap minat menjadi guru SD baik secara parsial maupun simultan. Jadi, faktor yang mempengaruhi motivasi mahasiswa menjadi guru antara lain persepsi mahasiswa terhadap status sosial guru dan persepsi mahasiswa tentang program Pendidikan Profesi Guru sebagai upaya peningkatan kompetensi (Sugiharto, 2018). Menurut Sinclair, Dowson, dan Mclnerney, motivasi menjadi guru akan berada pada jalur yang "benar" apabila mahasiswa menjalani pendidikan dan pelatihan sebagai upaya persiapan untuk menuju kehidupan profesional selanjutnya. Selama pelatihan 
mereka akan lebih termotivasi, lebih tertarik, lebih berpartisipasi aktif, dan cenderung akan konsisten untuk tetap memilih profesi ini. (Bruinsma \& Jansen, 2010). Selain itu, Malmberg menunjukkan salah satu motivasi menjadi guru adalah kecintaan pada mata pelajaran dan bekerja bersama anak-anak. Motivasi yang tumbuh dalam diri sendiri mampu mempengaruhi pemilihan strategi mengajar dan kepuasan pada pekerjaan, siswa juga menjadi lebih tertarik untuk belajar, dan guru menjadi lebih berkomitmen pada pekerjaan mereka. (Fokkens-Bruinsma \& Canrinus, 2014). Guru harus bisa menjalin hubungan yang baik dengan peserta didiknya sesuai dengan trilogi Ki Hajar Dewantara “Ing Ngarso Sung Tuladha, Ing Madya Mangun Karso, Tut Wuri Handayani (Dyah Indraswati, Arif Widodo, Aisa Nikmah Rahmatih, Mohammad Archi Maulyda, 2020). Guru harus memiliki kemampuan untuk obyektif, inklusif, tidak diskriminatif, dan mampu beradaptasi dengan peserta didik, orang tua, sesame penddik, dan masyarakat sekitar. (Puluhulawa, 2013).

Status sosial guru merujuk pada kedudukan relatif mengajar sebagai pekerjaan dalam hierarki semua pekerjaan. Karena status pekerjaan ditentukan oleh prestise, kekayaan, dan wewenang yang dinikmati. Status sosial juga merujuk pada rasa hormat yang diberikan kepada guru. (Fwu \& Wang, 2002). Dalam lingkungan masyarakat, guru merupakan teladan yang perilakunya menjadi panutan. Hal ini menuntut kemampuan sosial guru yang antara lain kemampuan berkomunikasi, bekerja sama, dan bergaul. Guru juga dipandang sebagai pemecah masalah dalam masyarakat karena dianggap sebagai orang yang terpelajar. (Rahadian, 2018). Di negara maju guru ditempatkan pada posisi yang sangat dihargai dan mendapatkan penghasilan yang tinggi, karena secara spesifik profesionalisme guru terlihat pada: (1) kemampuan untuk mengelola dan memimpin penyelenggaraan pendidikan; (2) kecakapan dan kemampuan intelektual; (3) perencanaan yang baik, efisien, konstektual, serta tepat dalam meningkatkan mutu SDM. Di Indonesia masyarakat menaruh harapan tinggi dari peran profesional guru, tetapi nasib guru kurang mendapat perhatian. Masih banyak guru yang mengambil profesi lain untuk mencukupi kebutuhan pokok terutama guru yang masih berstatus sebagai tenaga honorer. Tidak sedikit pula yang memilih pekerjaan sebagai guru karena kompensasi, tempat pelarian, atau karena tidak mendapat pekerjaan, padahal itu tidak sesuai dengan minat dan bakatnya. (Saat, 2014).

Pembangunan nasional sangat dipengaruhi oleh kualitas pendidikan, dan kualitas pendidikan dipengaruhi oleh kualitas guru (Indraswati, 2018). Peningkatan kualitas guru merupakan program strategis yang harus dilakukan pemerintah, seperti sertifikasi guru, uji kompetensi, pelatihan guru, dan penilaian kinerja guru. (Ratna Rosita Pangestika, 2015). Guru profesional dihasilkan melalui pendidikan akademik (S1) dan Pendidikan Profesi Guru (PPG). Perlu adanya sinergi kedua lembaga pendidikan dalam hal kurikulum, sarana prasarana, sumber daya manusia, dan program pengalaman lapangan, untuk menghasilkan guru yang memenuhi kualifikasi, kompetensi, dan sertifikat pendidik. (Ningrum, 2012). Pendidikan profesi guru mempersiapkan mahasiswa untuk praktik profesional mengatasi tantangan umum. Pendidikan profesional harus menemukan cara membantu mahasiswa membangun pengetahuan profesional dalam waktu yang relatif singkat, mengembangkan kebiasaan berpikir dan bersikap secara profesional, mempelajari keterampilan yang akan mereka butuhkan dalam praktik masa depan, mengembangkan cara-cara baru, dan membangun identitas profesional. (Chande, Khanwelkar, \& Barve, 2007). 


\section{MADRASAH}

Jurnal Pendidikan dan Pembelajaran Dasar

p ISSN: 1979-5599 | e ISSN: 2502-194X

P a g e | 143

Berdasarkan pemaparan di atas, tujuan penelitian ini adalah mengetahui : (1) pengaruh persepsi mahasiswa tentang status sosial guru terhadap motivasi mahasiswa menjadi guru SD; (2) pengaruh persepsi mahasiswa tentang program Pendidikan Profesi Guru (PPG) terhadap motivasi mahasiswa menjadi guru SD; (3) pengaruh persepsi mahasiswa tentang status sosial guru dan program Pendidikan Profesi Guru (PPG) secara simultan terhadap motivasi mahasiswa menjadi guru SD.

\section{B. METODE PENELITIAN}

Penelitian ini adalah penelitian ex-post facto menggunakan pendekatan kuantitatif. Cara pengumpulan data dengan kuesioner yang dikemas menggunakan google form dan disebarluaskan melalui aplikasi whatsapp. Analisis data menggunakan analisis regresi linear ganda. Penelitian ini dilakukan pada mahasiswa Program Studi Pendidikan Guru Sekolah Dasar semester 7, Universitas Mataram. Mahasiswa semester 7 dipilih karena dianggap paling siap untuk segera terjun ke profesi guru. Dari 315 mahasiswa semester 7, hanya 177 mahasiswa yang mengisi google form. Berdasarkan rumus Slovin dalam Riduwan (2005:65), 177 mahasiswa sudah dianggap representative. Dibulatkan menjadi 176. Jadi, berdasarkan rumus Slovin, 177 mahasiswa sudah dianggap representative. Penelitian ini dilaksanakan pada bulan Desember 2019 sampai Januari 2020. Kerangka berpikir dapat digambarkan pada skema penelitian berikut

Gambar A.1

Skema Penelitian

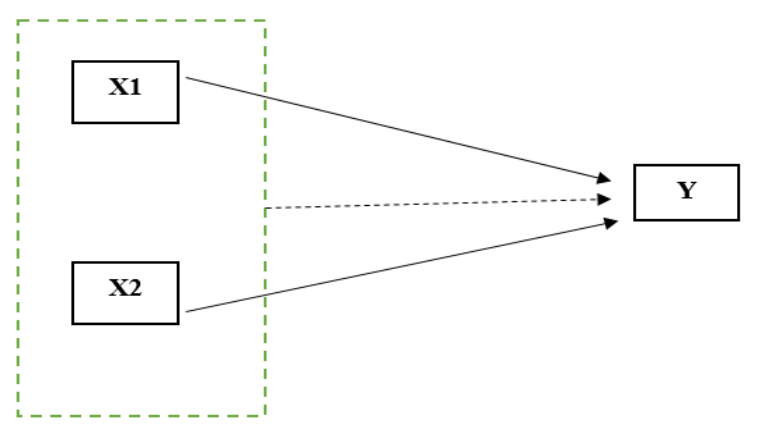

Keterangan:

X1 : persepsi mahasiswa tentang status sosial guru SD

X2 : persepsi mahasiswa tentang Pendidikan Profesi Guru (PPG)

Y $\quad$ : motivasi mahasiswa menjadi guru SD

$\longrightarrow \quad$ : pengaruh variabel bebas $(X)$ terhadap variabel terikat $(Y)$ secara parsial

$-\rightarrow \quad$ : pengaruh variabel bebas (X1 dan $X 2)$ terhadap variabel terikat $(Y)$ secara simultan

Hipotesis yang dirumuskan berdasar kerangka berpikir, meliputi:

1. Persepsi mahasiswa tentang status sosial guru memiliki pengaruh positif dan signifikan terhadap motivasi mahasiswa menjadi guru SD.

2. Persepsi mahasiswa tentang program Pendidikan Profesi Guru (PPG) memiliki pengaruh positif dan signifikan terhadap motivasi mahasiswa menjadi guru SD. 
3. Persepsi mahasiswa tentang status sosial guru dan Pendidikan Profesi Guru (PPG) secara simultan memiliki pengaruh positif dan signifikan terhadap motivasi mahasiswa menjadi guru SD.

\section{HASIL DAN PEMBAHASAN}

Tiga variabel dalam penelitian ini yaitu persepsi mahasiswa terhadap status sosial guru SD (X1), persepsi mahasiswa terhadap program Pendidikan Profesi Guru (X2), dan motivasi mahasiswa menjadi guru SD (Y).

\section{Hasil Pengujian Prasyarat Analisis}

\section{a. Uji Normalitas}

One-Sample Kolmogorov-Smirnov Test dipergunakan untuk melakukan uji normalitas. Kriteria yang digunakan dengan uji Asymp Sig (2 tailed) dengan taraf signifikansi 5\%.

Tabel A.1 One-Sample Kolmogorov-Smirnov Test

\begin{tabular}{|ll|r|r|r|}
\hline & & $\begin{array}{r}\text { Status Sosial } \\
\text { (X1) }\end{array}$ & PPG (X2) & Motivasi (Y) \\
\hline N & & 177 & 177 & 177 \\
Normal & Mean & 75,42 & 158.64 & 76,59 \\
Parametersa,b & Std. Deviation & 6,217 & 18.893 & 7,531 \\
Most Extreme $\quad$ Absolute & 0,095 & 0,177 & 0,079 \\
Differences & Positive & 0,095 & 0.177 & 0,079 \\
& Negative & $-0,071$ & -0.136 & $-0,077$ \\
Kolmogorov-Smirnov Z & $\mathbf{1 , 2 7 0}$ & $\mathbf{2 , 3 5 3}$ & $\mathbf{1 , 0 5 7}$ \\
Asymp. Sig. (2-tailed) & $\mathbf{0 , 0 7 9}$ & $\mathbf{0 , 0 0 0}$ & $\mathbf{0 , 2 1 4}$ \\
\hline
\end{tabular}

Berdasarkan hasil analisis diperoleh hasil untuk variabel status sosial guru, nilai Z K-S sebesar 1,270 dengan asymp sig 0,079. nilai asymp sig > 0,05 maka dapat disimpulkan data variabel status sosial berdistribusi normal. Variabel PPG memiliki nilai Z K-S sebesar 2,353 dengan asymp sig 0,000 $(<0,05)$, artinya data variabel PPG berdistribusi tidak normal. Variabel motivasi memiliki nilai Z K-S sebesar 0,214 dengan asymp. sig 0,214 (>0,05), artinya data variabel motivasi berdistribusi normal.

\section{b. Uji Linearitas}

Kriteria yang dipergunakan adalah uji $\mathrm{F}$ dengan taraf signifikansi 5\%. Jika nilai sig $\mathrm{F}<$ 0,05 maka hubungannya tidak linear, sedangkan jika nilai sig $\mathrm{F} \geq 0,05$ maka hubungannya linear.

Tabel A. 2

Hubungan Antara Variabel Status Sosial Guru dan Motivasi Menjadi Guru

\begin{tabular}{|c|c|c|c|c|c|c|c|}
\hline & $\begin{array}{l}\text { Sum of } \\
\text { Squares }\end{array}$ & df & $\begin{array}{l}\text { Mean } \\
\text { Square }\end{array}$ & F & Sig. \\
\hline $\begin{array}{l}\text { Motiva } \\
\text { i * }\end{array}$ & $\begin{array}{l}\text { Between } \\
\text { Groups }\end{array}$ & $\begin{array}{l}\text { (Combine } \\
\text { d) }\end{array}$ & 4714,355 & 25 & 188,574 & 5,405 & 0,000 \\
\hline Status & & Linearity & 2580,743 & 1 & 2580,743 & 73,968 & 0,000 \\
\hline Sosial & & $\begin{array}{l}\text { Deviation } \\
\text { from } \\
\text { Linearity }\end{array}$ & 2133,612 & 24 & 88,901 & 2,548 & 0,000 \\
\hline \multicolumn{3}{|c|}{ Within Groups } & 5268,357 & 151 & \multirow[t]{2}{*}{34,890} & & \\
\hline \multicolumn{3}{|c|}{ Total } & 9982,712 & 176 & & & \\
\hline
\end{tabular}




\section{MADRASAH}

Jurnal Pendidikan dan Pembelajaran Dasar

Berdasarkan hasil analisis, nilai F yang ditemukan 2,548 dengan sig 0,000. Oleh karena nilai sig $<0,05$ maka dapat disimpulkan bahwa hubungan antara variabel status sosial guru dan motivasi menjadi guru tidak linear.

Tabel A. 3 Hubungan Antara Variabel PPG dan Motivasi Menjadi Guru

\begin{tabular}{|c|c|c|c|c|c|c|}
\hline & Sum of Squares & df & $\begin{array}{c}\text { Mean } \\
\text { Square }\end{array}$ & $\mathbf{F}$ & Sig. \\
\hline \multirow{3}{*}{$\begin{array}{l}\text { Moti Between } \\
\text { vasi * Groups } \\
\text { PPG }\end{array}$} & $\begin{array}{l}\text { (Combine } \\
\text { d) }\end{array}$ & 6955,873 & 43 & 161,764 & 7,108 & 0,000 \\
\hline & Linearity & 1676,789 & 1 & 1676,789 & 73,678 & 0,000 \\
\hline & $\begin{array}{l}\text { Deviation } \\
\text { from } \\
\text { Linearity }\end{array}$ & 5279,084 & 42 & 125,692 & 5,523 & 0,000 \\
\hline \multicolumn{2}{|c|}{ Within Groups } & 3026,839 & 133 & 22,758 & & \\
\hline \multicolumn{2}{|l|}{ Total } & 9982,712 & 176 & & & \\
\hline
\end{tabular}

Berdasarkan hasil analisis, nilai F yang ditemukan 5,523 dengan sig 0,000. Oleh karena nilai sig < 0,05 artinya hubungan antara variabel PPG dan motivasi menjadi guru tidak linear.

\section{c. Uji Multikolinearitas}

Uji VIF (Variance Inflation Factor) digunakan untuk melakukan uji multikolinearitas. Jika nilai tolerance $>0,25$ dan VIF $<4$ maka tidak terjadi multikolinearitas, sedangkan jika nilai tolerance $<0,25$ dan VIF $>4$ maka terjadi multikolinearitas.

Tabel A. 4 Hasil Uji Multikolinearitas

\begin{tabular}{|c|c|c|c|c|c|c|c|c|c|c|}
\hline \multirow[t]{2}{*}{ Model } & \multicolumn{2}{|c|}{$\begin{array}{l}\text { Unstandardiz } \\
\text { ed } \\
\text { Coefficients }\end{array}$} & \multirow{2}{*}{ 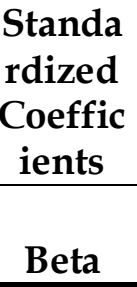 } & \multirow[b]{2}{*}{$\mathbf{t}$} & \multirow[b]{2}{*}{ Sig. } & \multicolumn{3}{|c|}{ Correlations } & \multicolumn{2}{|c|}{$\begin{array}{c}\text { Collinearity } \\
\text { Statistics }\end{array}$} \\
\hline & B & $\begin{array}{l}\text { Std. } \\
\text { Error }\end{array}$ & & & & $\begin{array}{l}\text { Zero- } \\
\text { order }\end{array}$ & Partial & Part & $\begin{array}{l}\text { Toler } \\
\text { ance }\end{array}$ & VIF \\
\hline (Constant) & 27.556 & 5.972 & & 4.614 & 0,000 & & & & & \\
\hline Status Sosial & 0,491 & 0,093 & 0,405 & 5,307 & 0,000 & 0,508 & 0,373 & 0,340 & 0,705 & 1,418 \\
\hline PPG & 0,076 & 0,030 & 0,190 & 2,483 & 0,014 & 0,410 & 0,185 & 0,159 & 0,705 & 1,418 \\
\hline
\end{tabular}

Kesimpulannya adalah tidak terjadi multikolinearitas antar variabel bebas karena nilai tolerance $0,705(>0,25)$ dan nilai VIF $<4$.

\section{Pengujian Hipotesis}

a. Pengaruh Persepsi Mahasiswa tentang Status Sosial Guru Terhadap Motivasi Menjadi Guru SD.

Untuk mengetahui apakah terdapat pengaruh persepsi mahasiswa tentang status sosial guru terhadap motivasi mahasiswa menjadi guru SD dilakukan analisis 
dengan menggunakan analisis regresi sederhana dengan program SPSS v.18 for Windows. Ringkasan hasil analisis uji regresi dapat dilihat pada tabel.

Tabel A. 5 Hasil Uji Regresi Sederhana (X1-Y)

\begin{tabular}{|c|c|c|c|c|c|c|c|c|c|}
\hline \multirow[t]{2}{*}{ Model } & \multirow[t]{2}{*}{$\mathbf{R}$} & \multirow[t]{2}{*}{ R Square } & \multirow{2}{*}{$\begin{array}{l}\text { Adjusted } \\
\text { R Square }\end{array}$} & \multirow{2}{*}{$\begin{array}{l}\text { Std. Error } \\
\text { of the } \\
\text { Estimate }\end{array}$} & \multicolumn{5}{|c|}{ Change Statistics } \\
\hline & & & & & $\begin{array}{l}\text { R } \\
\text { Square } \\
\text { Change }\end{array}$ & $\begin{array}{l}\text { F } \\
\text { Change }\end{array}$ & Df1 & Df2 & $\begin{array}{l}\text { Sig. F } \\
\text { Change }\end{array}$ \\
\hline 1 & $\begin{array}{l}0,50 \\
8^{a}\end{array}$ & 0,259 & 0,254 & 6,504 & 0,259 & 61,015 & 1 & 175 & 0,000 \\
\hline
\end{tabular}

$\mathrm{R}=0,508$ artinya koefisien korelasi sebesar 0,508. Angka koefisien determinasinya $\left(R^{2}\right)$ ditunjukkan dengan $R$ Square $=0,259$. Maksudnya adalah variansi dalam motivasi menjadi guru dapat dijelaskan dengan persepsi mahasiswa tentang status sosial guru melalui model sebesar $25,9 \%$, sisanya berasal dari variabel lain sebesar 74,1 \%. Adjusted R Square = 0,254. Maknanya sama dengan R square, adjusted $\mathrm{R}$ square nilainya lebih stabil karena sudah disesuaikan dengan variabel bebasnya.

Tabel A. 6 Hasil Pengujian Koefisien Determinasi

\begin{tabular}{|l|r|r|r|r|c|}
\hline \multicolumn{1}{|c|}{ Model } & \multicolumn{1}{c|}{$\begin{array}{c}\text { Sum of } \\
\text { Squares }\end{array}$} & \multicolumn{1}{c|}{ df } & $\begin{array}{c}\text { Mean } \\
\text { Square }\end{array}$ & \multicolumn{1}{c|}{ F } & Sig. \\
\hline 1 Regression & 2580,743 & 1 & 2580,743 & 61,015 & $0,000^{a}$ \\
Residual & 7401,969 & 175 & 42,297 & & \\
Total & 9982,712 & 176 & & & \\
\hline
\end{tabular}

Hasil uji koefisien determinasi. Harga $\mathrm{F}$ hitung sebesar 61,015 dengan sig. $=$ 0,000. Nilai sig. $<0,05$ maka Ho $(\rho=0)$ ditolak, artinya persepsi mahasiswa tentang status sosial guru memiliki pengaruh yang signifikan terhadap motivasi mahasiswa menjadi guru SD.

Tabel A. 7 Persamaan Garis Regresi

\begin{tabular}{|c|c|c|c|c|c|c|c|c|c|c|}
\hline \multirow[t]{2}{*}{ Model } & \multicolumn{3}{|c|}{\begin{tabular}{|c|c|c|} 
Unstandardized & $\begin{array}{l}\text { Standa } \\
\text { rdized } \\
\text { Coeffic } \\
\text { Coefficients }\end{array}$ & $\begin{array}{l}\text { ients } \\
\text { ients }\end{array}$ \\
\end{tabular}} & \multirow[b]{2}{*}{$t$} & \multirow[b]{2}{*}{ Sig. } & \multicolumn{3}{|c|}{ Correlations } & \multicolumn{2}{|c|}{$\begin{array}{c}\text { Collinearity } \\
\text { Statistics }\end{array}$} \\
\hline & B & $\begin{array}{l}\text { Std. } \\
\text { Error }\end{array}$ & Beta & & & $\begin{array}{l}\text { Zero- } \\
\text { order }\end{array}$ & Partial & Part & $\begin{array}{c}\text { Tolera } \\
\text { nce }\end{array}$ & VIF \\
\hline (Constant) & 30,142 & 5,967 & & 5,052 & 0,000 & & & & & \\
\hline $\begin{array}{l}\text { Status } \\
\text { Sosial }\end{array}$ & 0,616 & 0,079 & 0,508 & 7,811 & 0,000 & 0,508 & 0,508 & 0,508 & 1,000 & 1,000 \\
\hline
\end{tabular}

$\mathrm{Y}^{\prime}=30,142+0,616 \mathrm{X}$ adalah persamaan garis regresi yang diperoleh dari kolom Unstandardized Coefficients. Nilai t hitung adalah 7,811 dengan sig. $=0,000$. Nilai sig. $<$ 0,05 maka Ho $(\beta=0)$ ditolak, artinya persepsi mahasiswa tentang status sosial guru berpengaruh positif dan signifikan terhadap motivasi mahasiswa menjadi guru SD. Semakin baik persepsi mahasiswa tentang status sosial guru semakin tinggi motivasi mahasiswa menjadi guru SD. 


\section{MADRASAH}

Jurnal Pendidikan dan Pembelajaran Dasar

p ISSN: 1979-5599 | e ISSN: 2502-194X

\section{b. Pengaruh Persepsi Mahasiswa Tentang Pendidikan Profesi Guru (PPG)}

Terhadap Motivasi Mahasiswa Menjadi Guru SD.

Ringkasan hasil analisis regresi dapat dilihat pada tabel berikut:

Tabel A. 8 Hasil Uji Regresi (X2-Y)

\begin{tabular}{|c|c|c|c|c|c|c|c|c|c|}
\hline \multirow[t]{2}{*}{ Model } & \multirow[t]{2}{*}{$\mathbf{R}$} & \multirow{2}{*}{$\begin{array}{c}\mathbf{R} \\
\text { Square }\end{array}$} & \multirow{2}{*}{$\begin{array}{l}\text { Adjusted } \\
\text { R Square }\end{array}$} & \multirow{2}{*}{$\begin{array}{c}\text { Std. } \\
\text { Error of } \\
\text { the } \\
\text { Estimate }\end{array}$} & \multicolumn{5}{|c|}{ Change Statistics } \\
\hline & & & & & $\begin{array}{c}\text { R } \\
\text { Square } \\
\text { Change }\end{array}$ & $\begin{array}{c}\text { F } \\
\text { Change }\end{array}$ & Df1 & Df2 & $\begin{array}{l}\text { Sig. F } \\
\text { Change }\end{array}$ \\
\hline 1 & $0,410^{\mathrm{a}}$ & 0,168 & 0,163 & 6,889 & 0,168 & 35,329 & 1 & 175 & 0,000 \\
\hline
\end{tabular}

$\mathrm{R}=0,410$ artinya koefisien korelasinya sebesar $0,410 . \mathrm{R}$ Square $=0,168$ menunjukkan angka koefisien determinasinya $\left(R^{2}\right)$. Artinya variansi dalam prestasi dapat dijelaskan oleh motivasi belajar melalui model sebesar $16,8 \%$, berasal dari variabel lain sebesar 83,2\%. Adjusted $\mathrm{R}$ Square $=0,163$. Maknanya sama dengan $\mathrm{R}$ square, tetapi nilainya lebih stabil karena sudah disesuaikan dengan jumlah variabel bebas.

Tabel A. 9 Hasil Pengujian Koefisien Determinasi

\begin{tabular}{|c|r|r|r|r|r|}
\hline Model & \multicolumn{1}{|c|}{$\begin{array}{c}\text { Sum of } \\
\text { Squares }\end{array}$} & \multicolumn{1}{c|}{ df } & $\begin{array}{c}\text { Mean } \\
\text { Square }\end{array}$ & F & Sig. \\
\hline 1 Regression & 1676,789 & 1 & 1676,789 & 35,329 & $0,000^{\mathrm{a}}$ \\
Residual & 8305,923 & 175 & 47,462 & & \\
Total & 9982,712 & 176 & & & \\
\hline
\end{tabular}

Harga F hitung sebesar 35,329 dengan sig. $=0,000$. Nilai sig. $<0,05$ maka Ho $(\rho=$ 0) ditolak, artinya persepsi mahasiswa tentang pendidikan profesi guru (PPG) memiliki pengaruh yang signifikan terhadap motivasi mahasiswa menjadi guru SD.

Tabel A. 10 Persamaan Garis Regresi dan Pengujiannya

\begin{tabular}{|c|c|c|c|c|c|c|c|c|c|c|}
\hline \multirow[t]{2}{*}{ Model } & \multicolumn{2}{|c|}{$\begin{array}{c}\text { Unstandardiz } \\
\text { ed } \\
\text { Coefficients }\end{array}$} & \multirow{2}{*}{$\begin{array}{c}\text { Standa } \\
\text { rdized } \\
\text { Coeffic } \\
\text { ients }\end{array}$} & \multirow[t]{2}{*}{$t$} & \multirow[t]{2}{*}{ Sig. } & \multicolumn{3}{|c|}{ Correlations } & \multicolumn{2}{|c|}{$\begin{array}{l}\text { Collinearity } \\
\text { Statistics }\end{array}$} \\
\hline & B & $\begin{array}{l}\text { Std. } \\
\text { Error }\end{array}$ & & & & $\begin{array}{l}\text { Zero- } \\
\text { order }\end{array}$ & $\begin{array}{c}\text { Partia } \\
1\end{array}$ & Part & $\begin{array}{l}\text { Toler } \\
\text { ance }\end{array}$ & VIF \\
\hline $\begin{array}{l}\text { (Const } \\
\text { ant) }\end{array}$ & 50,675 & 4,391 & & 11,540 & 0,000 & & & & & \\
\hline PPG & 0,163 & 0,027 & 0,410 & 5,944 & 0,000 & 0,410 & 0,410 & 0,410 & 1,000 & 1,000 \\
\hline
\end{tabular}

$\mathrm{Y}^{\prime}=50,675+0,163 \mathrm{X}$ merupakan persamaan garis regresi yang diperoleh pada kolom Unstandardized Coefficients. Nilai t hitung sebesar 5,944 dengan sig. $=0,000$. Nilai sig. $<0,05$ maka Ho $(\beta=0)$ ditolak, artinya persepsi mahasiswa tentang Pendidikan Profesi Guru (PPG) berpengaruh positif dan signifikan terhadap motivasi mahasiswa menjadi guru SD. Semakin baik persepsi mahasiswa tentang Pendidikan Profesi Guru (PPG) semakin tinggi motivasi mahasiswa menjadi guru SD. 


\section{c. Pengaruh Persepsi Mahasiswa Tentang Status Sosial Guru dan PPG secara simultan terhadap Motivasi Mahasiswa Menjadi Guru. \\ Untuk mengetahui apakah terdapat pengaruh persepsi mahasiswa tentang} status sosial guru dan Pendidikan Profesi Guru (PPG) secara simultan terhadap motivasi mahasiswa menjadi guru SD dilakukan analisis dengan menggunakan analisis regresi ganda dengan program SPSS v.18 for Windows.

Tabel A. 11 Hasil Uji Regresi Ganda

\begin{tabular}{|c|c|c|c|c|c|c|c|c|c|}
\hline \multirow[t]{2}{*}{ Model } & \multirow[t]{2}{*}{$\mathbf{R}$} & \multirow{2}{*}{$\begin{array}{c}\mathbf{R} \\
\text { Square }\end{array}$} & \multirow{2}{*}{$\begin{array}{l}\text { Adjusted } \\
\text { R Square }\end{array}$} & \multirow{2}{*}{$\begin{array}{c}\text { Std. } \\
\text { Error of } \\
\text { the } \\
\text { Estimate }\end{array}$} & \multicolumn{5}{|c|}{ Change Statistics } \\
\hline & & & & & $\begin{array}{c}\text { R } \\
\text { Square } \\
\text { Change }\end{array}$ & $\begin{array}{c}\text { F } \\
\text { Change }\end{array}$ & Df1 & Df2 & $\begin{array}{l}\text { Sig. F } \\
\text { Change }\end{array}$ \\
\hline 1 & $0,533^{a}$ & 0,284 & 0,276 & 6.410 & 0.284 & 34,490 & 2 & 174 & 0,000 \\
\hline
\end{tabular}

$\mathrm{R}=0,533$, artinya koefisien korelasinya sebesar 0,533. angka koefisien determinasinya $\left(R^{2}\right)$ ditunjukkan dengan $R$ Square $=0,284$. Artinya variansi dalam motivasi menjadi guru dapat dijelaskan oleh persepsi mahasiswa tentang status sosial guru dan PPG melalui model sebesar 28,4\%, sedangkan dari variabel lain sebesar $71,6 \%$. Adjusted R square = 0,276. Ukuran ini maknanya sama dengan R square, tetapi nilainya lebih stabil kareana sudah disesuaikan dengan jumlah variabel bebasnya.

Tabel A. 12 ANOVA $^{b}$

\begin{tabular}{|l|r|r|r|r|c|}
\hline \multicolumn{1}{|c|}{ Model } & \multicolumn{1}{c|}{$\begin{array}{c}\text { Sum of } \\
\text { Squares }\end{array}$} & \multicolumn{1}{c|}{ df } & $\begin{array}{c}\text { Mean } \\
\text { Square }\end{array}$ & F & Sig. \\
\hline 1 Regression & 2834,011 & 2 & 1417,005 & 34,490 & $0,000 \mathrm{a}$ \\
Residual & 7148,701 & 174 & 4,084 & & \\
Total & 9982,712 & 176 & & & \\
\hline
\end{tabular}

Hasil pengujian koefisien determinasi ditemukan harga $\mathrm{F}$ hitung sebesar 34,490 dengan sig. $=0,000$. Oleh karena nilai sig. $<0,05$ maka Ho $(p=0)$ ditolak yang artinya persepsi mahasiswa tentang status sosial guru dan Pendidikan Profesi Guru (PPG) secara simultan memiliki pengaruh yang signifikan terhadap motivasi mahasiswa menjadi guru SD.

Tabel A. 13 Persamaan Garis Regresi

\begin{tabular}{|c|c|c|c|c|c|c|c|c|c|c|}
\hline \multirow[t]{2}{*}{ Model } & \multicolumn{2}{|c|}{$\begin{array}{l}\text { Unstandardize } \\
\text { d Coefficients }\end{array}$} & \multirow{2}{*}{\begin{tabular}{|c|}
$\begin{array}{l}\text { Standa } \\
\text { rdized } \\
\text { Coeffic } \\
\text { ients }\end{array}$ \\
Beta \\
\end{tabular}} & \multirow[b]{2}{*}{$\mathbf{t}$} & \multirow[b]{2}{*}{ Sig. } & \multicolumn{3}{|c|}{ Correlations } & \multicolumn{2}{|c|}{$\begin{array}{c}\text { Collinearity } \\
\text { Statistics }\end{array}$} \\
\hline & B & $\begin{array}{l}\text { Std. } \\
\text { Error }\end{array}$ & & & & $\begin{array}{l}\text { Zero- } \\
\text { order }\end{array}$ & $\begin{array}{c}\text { Partia } \\
1\end{array}$ & Part & $\begin{array}{l}\text { Toler } \\
\text { ance }\end{array}$ & VIF \\
\hline $\begin{array}{ll}1 & \text { (Consta } \\
\text { nt) }\end{array}$ & 27,556 & 5,972 & & 4,614 & 0,000 & & & & & \\
\hline $\begin{array}{l}\text { Status } \\
\text { Sosial }\end{array}$ & 0,491 & 0,093 & 0,405 & 5,307 & 0,000 & 0,508 & 0,373 & 0,340 & 0,705 & 1,418 \\
\hline PPG & 0,076 & 0,030 & 0,190 & 2,483 & 0,014 & 0,410 & 0,185 & 0,159 & 0,705 & 1,418 \\
\hline
\end{tabular}




\section{MADRASAH}

Jurnal Pendidikan dan Pembelajaran Dasar

p ISSN: 1979-5599 | e ISSN: 2502-194X

P a g e | 149

$\mathrm{Y}^{\prime}=27,556+0,491 \mathrm{X} 1+0,76 \mathrm{X} 2$ adalah persamaan garis regresinya. Koefisien garisnya dilihat pada kolom $\mathbf{t}$ dan sig. Untuk variabel persepsi mahasiswa tentang status sosial guru (X1) ditemukan nilai $b 1=0,491$ dengan $t=5,307$ dan sig. 0,000 . Nilai sig. $<0,05$ maka H0 $\left(\beta_{1}=0\right)$ ditolak, artinya variabel persepsi mahasiswa tentang status sosial guru berpengaruh positif terhadap motivasi mahasiswa menjadi guru jika variabel persepsi mahasiswa terhadap PPG dikendalikan atau dikontrol. Untuk variabel persepsi mahasiswa tentang PPG (X2) ditemukan nilai $\mathrm{b} 2=0,076$ dengan $\mathrm{t}=$ 2,483 dan Sig. $=0,014$. Oleh karena nilai sig. $<0,05$ maka Ho $\left(\beta_{2}=0\right)$ ditolak yang artinya variabel persepsi mahasiswa terhadap Pendidikan Profesi Guru (PPG) berpengaruh positif terhadap motivasi mahasiswa menjadi guru SD jika variabel persepsi mahasiswa tentang status sosial guru dikendalikan/dikontrol.

\section{d. Sumbangan Relatif (SR) dan Sumbangan Efektif (SE)}

Ringkasan hasil perhitungan sumbangan relatif dan efektif dapat dilihat pada tabel dibawah ini:

Tabel A. 14 Correlations

\begin{tabular}{|c|c|c|c|c|}
\hline & & $\begin{array}{l}\text { Status Sosial } \\
\text { (X1) }\end{array}$ & $\begin{array}{l}\text { PPG } \\
(\mathrm{X} 2)\end{array}$ & Motivasi (Y) \\
\hline \multirow[t]{5}{*}{ Status Sosial } & Pearson Correlation & 1 & $0,543^{* *}$ & $0,508^{* *}$ \\
\hline & Sig. (2-tailed) & & 0,000 & 0,000 \\
\hline & $\begin{array}{l}\text { Sum of Squares and } \\
\text { Cross-products }\end{array}$ & 6803,062 & 11225,339 & 4190,102 \\
\hline & Covariance & 38,654 & 63,780 & 23,807 \\
\hline & $\mathrm{N}$ & 177 & 177 & 177 \\
\hline \multirow[t]{5}{*}{ PPG } & Pearson Correlation & $0,543^{* *}$ & 1 & $0,410^{* *}$ \\
\hline & Sig. (2-tailed) & 0,000 & & 0,000 \\
\hline & Sum of Squares and & 11225,339 & 62820,576 & 10263,373 \\
\hline & $\begin{array}{l}\text { Cross-products } \\
\text { Covariance }\end{array}$ & 63,780 & 356,935 & 58,315 \\
\hline & $\mathrm{N}$ & 177 & 177 & 177 \\
\hline \multirow[t]{5}{*}{ Motivasi } & Pearson Correlation & $0,508^{* *}$ & $0,410^{* *}$ & 1 \\
\hline & Sig. (2-tailed) & 0,000 & 0,000 & \\
\hline & $\begin{array}{l}\text { Sum of Squares and } \\
\text { Cross-products }\end{array}$ & 4190,102 & 10263,373 & 9982,712 \\
\hline & Covariance & 23,807 & 58,315 & 56,720 \\
\hline & $\mathrm{N}$ & 177 & 177 & 177 \\
\hline
\end{tabular}

Tabel A. 15 Ringkasan Hasil Dari Analisis Korelasi Dan Regresi

\begin{tabular}{cccc}
\hline Variabel & $\begin{array}{c}\text { Koefisien Regresi } \\
(\text { Beta) }\end{array}$ & $\begin{array}{c}\text { Koefisien Korelasi } \\
(\mathbf{r})\end{array}$ & $\mathbf{R}_{\text {square }}$ \\
\hline $\mathrm{X} 1$ & 0,405 & $0,508^{* *}$ & 0,284 \\
\hline $\mathrm{X} 2$ & 0,190 & $0,410^{* *}$ & \\
\hline
\end{tabular}


Berdasarkan perhitungan sumbangan relatif (SR\%) dan sumbangan efektif (SE\%)

Tabel A. 16 Ringkasan Bobot Sumbangan Variabel Bebas Terhadap Variabel Terikat

\begin{tabular}{ccc}
\hline Prediktor & Sumbangan Relatif (SR) \% & Sumbangan Efektif (SE) $\%$ \\
\hline $\begin{array}{c}\text { Persepsi Mahasiswa } \\
\text { Tentang Status Sosial } \\
\text { Guru (X1) }\end{array}$ & 72,43 & 20,57 \\
\hline $\begin{array}{c}\text { Persepsi Mahasiswa } \\
\text { Tentang PPG (X2) }\end{array}$ & 27,43 & 7,79 \\
\hline Total & 99,86 dibulatkan menjadi 100 & 28,4 \\
\hline
\end{tabular}

Berdasarkan hasil perhitungan diatas dapat diketahui bahwa sumbangan efektif (SE) variabel persepsi mahasiswa tentang status sosial guru (X1) terhadap motivasi mahasiswa menjadi guru (Y) sebesar 20,57\%. Sementara sumbangan efektif (SE) variabel persepsi mahasiswa tentang PPG (X2) terhadap motivasi mahasiswa menjadi guru (Y) sebesar 7,79\%. Dengan demikian dapat disimpulkan bahwa variabel X1 memiliki pengaruh lebih dominan terhadap variabel Y. Untuk total SE adalah sebesar $28,4 \%$ atau sama dengan koefisien determinasi (RSquare) analisis regresi yakni 28,4\%.

Sumbangn relatif (SR) variabel persepsi mahasiswa tentang profesi guru (X1) terhadap motivasi mahasiswa menjadi guru (Y) sebesar 72,43\%. Sumbangan relatif (SR) variabel persepsi mahasiswa tentang PPG (X2) terhadap motivasi mahasiswa menjadi guru (Y) sebesar 27,43\%.Untuk total SR adalah sebesar 100\% atau sama dengan 1 .

\section{PEMBAHASAN}

\section{Pengaruh persepsi mahasiswa tentang status sosial guru SD terhadap motivasi mahasiswa menjadi guru SD.}

Hasil penelitian menunjukkan terdapat pengaruh positif dan signifikan persepsi mahasiswa tentang status sosial guru SD terhadap motivasi menjadi guru SD. Ini menunjukkan bahwa semakin tinggi mahasiswa mempersepsikan status sosial guru maka akan semakin tinggi pula motivasi mahasiswa menjadi guru SD. Persepsi mahasiswa tinggi pada status sosial guru terlihat pada indicator prestise antara lain penghargaan terhadap profesi guru, kesejahteraan guru, dan kedudukan serta martabat guru. Tingginya persepsi mahasiswa tentang prestise seorang guru membuat semakin tinggi motivasi dan kemantapan mahasiswa menjadi guru. Hasil penelitian ini mendukung hasil penelitian yang dilakukan oleh Heni Martya (2015) yang menyatakan terdapat pengaruh positif yang signifikan persepsi mahasiswa tentang status sosial guru terhadap motivasi menjadi guru. Semakin baik persepsi mahasiswa tentang status sosial guru semakin tinggi motivasi mahasiswa menjadi guru. Penelitian ini juga senada dengan teori yang diungkapkan Abraham Maslow tentang "hierarki kebutuhan". Motivasi seseorang dilandasi oleh kebutuhan akan pengakuan status dan penghargaan (Martya, 2015).

\section{Pengaruh persepsi mahasiswa tentang Pendidikan Profesi Guru (PPG) terhadap motivasi mahasiswa menjadi guru SD.}

Hasil penelitian menunjukkan terdapat pengaruh positif dan signifikan persepsi mahasiswa tentang PPG terhadap motivasi mahasiswa menjadi guru SD. Semakin baik persepsi mahasiswa tentang Pendidikan Profesi Guru (PPG) semakin tinggi motivasi mahasiswa menjadi guru SD. Hasil penelitian ini sesuai dengan penelitian yang 


\section{MADRASAH}

Jurnal Pendidikan dan Pembelajaran Dasar

p ISSN: 1979-5599 | e ISSN: 2502-194X

dilakukan Shintya Oktaviani Karunia (2012) yang menyatakan bahwa kompetensi guru berpengaruh terhadap motivasi mahasiswa menjadi guru. Mahasiswa PGSD universitas Mataram memandang program PPG sangat mendukung kompetensi pedagogic, kompetensi kepribadian, kompetensi sosial, dan kompetensi profesional. Penguasaan kompetensi secara utuh melalui program PPG serta adanya sertifikat pendidik tentu akan meningkatkan motivasi mahasiswa menjadi seorang guru.

\section{Pengaruh persepsi mahasiswa tentang status sosial guru dan Pendidikan Profesi Guru (PPG) terhadap motivasi mahasiswa menjadi guru SD.}

Hasil penelitian menunjukkan terdapat pengaruh positif dan signifikan variabel persepsi mahasiswa tentang status sosial guru dan PPG secara simultan terhadap motivasi mahasiswa menjadi guru. Hasil uji $\mathrm{F}$ menunjukkan $\mathrm{F}$ hitung sebesar 34.490 dengan signifikansi $0,000(<0,05)$ sehingga dinyatakan bahwa variabel persepsi mahasiswa tentang status sosial guru dan PPG secara simultan berpengaruh secara signifikan terhadap motivasi mahasiswa menjadi guru. Nilai koefisien determinasi $\left(\mathrm{R}^{2}\right)$ sebesar 0,284, maka model regresi variabel persepsi mahasiswa tentang status sosial guru dan PPG dapat menjelaskan motivasi menjadi guru sebesar 28,4\%. Angka ini menunjukkan bahwa persepsi mahasiswa tentang status sosial guru dan PPG memiliki pengaruh terhadap motivasi mahasiswa menjadi guru sebesar $28,4 \%$ sedangkan sisanya $71,6 \%$ dipengaruhi variabel lain di luar penelitian.

\section{KESIMPULAN}

Berdasarkan pembahasan yang telah diuraikan, maka diperoleh kesimpulan sebagai berikut:

1. Terdapat pengaruh positif dan signifikan persepsi mahasiswa tentang status sosial guru terhadap motivasi menjadi guru SD. Besar pengaruhnya sebesar 25,9\% dan dari variabel lain sebesar 74,1 \%. Fakta penelitian dapat menjadi bahan evaluasi bagi para pemangku kebijakan pendidikan dan juga pendidik untuk lebih memberikan gambaran kepada mahasiswa tentang profesinya di masa yang akan datang. Perlu adanya pengalaman dan program yang disusun sebagai stimulus agar mahasiswa senantiasa memiliki persepsi yang positif tentang status sosial guru bukan hanya dari segi prestise saja tetapi juga dari peran dan teladan yang harus dimiliki oleh guru.

2. Terdapat pengaruh positif dan signifikan persepsi mahasiswa tentang Pendidikan Profesi Guru (PPG) terhadap motivasi menjadi guru SD. Besar pengaruhnya adalah $16,8 \%$, sisanya sebesar $83,2 \%$ berasal dari variabel lain. Penting bagi prodi khususnya PGSD meningkatkan performanya menyiapkan lulusan yang memiliki keahlian dan kompetensi di bidang ke-SDan sehingga program PPG membuat mereka semakin matang menjalankan profesinya.

3. Terdapat pengaruh positif dan signifikan variabel persepsi mahasiswa tentang status sosial guru dan Pendidikan Profesi Guru secara simultan terhadap motivasi mahasiswa menjadi guru SD. persepsi mahasiswa tentang status sosial guru dan PPG memiliki pengaruh terhadap motivasi mahasiswa menjadi guru sebesar $28,4 \%$ sedangkan sisanya 71,6\% dipengaruhi variabel lain di luar penelitian. Perlu adanya 
penelitian lebih lanjut tentang variabel lain yang berpengaruh terhadap motivasi mahasiswa menjadi seorang guru.

\section{REFERENSI}

Bruinsma, M., \& Jansen, E. P. W. A. (2010). Is the motivation to become a teacher related to pre-service teachers' intentions to remain in the profession? European Journal of Teacher Education, 33(2), 185-200. https:/ / doi.org/10.1080/02619760903512927

Chande, M. S., Khanwelkar, R. R., \& Barve, P. A. (2007). Synthesis of novel spiro compounds using anthrone and pyrazole-5-thione moieties: A Michael addition approach. Journal of Chemical Research, 111(8), 468-471. https:/ / doi.org/10.3184/030823407X237821

Dantes, N. (2007). Pendidikan Profesi Guru Dalam Kaitannya Dengan Peningkatan Profesionalisme Guru (Refleksi tentang Struktur Program LPTK). JurnalPendidikan dan Pengajaran UNDIKSHA, Edisi khus(Mei), 452-471.

Dyah Indraswati, Arif Widodo, Aisa Nikmah Rahmatih, Mohammad Archi Maulyda, M. E. (2020). Implementasi Sekolah Ramah Anak Dan Keluarga Di Sdn 2 Hegarsari, Sdn Kaligintung, Dan Sdn 1 Sangkawana. JKKP: Jurnal Kesejahteraan Kelaurga Dan Pendidikan, 7(April), 51-62. https://doi.org/: http://doi.org/10.21009/JKKP.071.05

Fokkens-Bruinsma, M., \& Canrinus, E. T. (2014). Motivation for becoming a teacher and engagement with the profession: Evidence from different contexts. International Journal of Educational Research, 65, 65-74. https:// doi.org/10.1016/j.ijer.2013.09.012

Fwu, B. J., \& Wang, H. H. (2002). The sosial status of teachers in Taiwan. Comparative Education, 38(2), 211-224. https:/ / doi.org/10.1080/03050060220140584

I Ketut Margi, N. B. A. (2013). Program Pendidikan Profesi Guru Prajabatan Dalam Perspektif Darwinisme Sosial. Jurnal Pendidikan Dan Pengajaran, 46(1), 87-95.

Indraswati, D. (2018). Efektivitas Model Pembelajaran Kooperatif Tipe Numbered Heads Together ( NHT ) Terhadap : Kompetensi Sikap Siswa, Kompetensi. Journal Research And Analysis: Economy, 1(2), 52-58. Retrieved from https://journal.stkipsingkawang.ac.id/index.php/JRAE/article/view/953

Martya, H. (2015). Pengaruh Persepsi Mahasiswa Tentang Status Sosial Guru dan Program Pendidikan Profesi Guru (PPG) Terhadap Motivasi Menjadi Guru (Universitas Negeri $\begin{array}{llll}\text { Yogyakarta; } & \text { Vol. } & \text { 3). } & \text { Retrieved }\end{array}$ http:/ / repositorio.unan.edu.ni/2986/1/5624.pdf

Ningrum, E. (2012). Membangun Sinergi Pendidikan Akademik ( S1 ) Dan Pendidikan Profesi Guru (PPG ). Jurnal Pendidikan Geografi (GEA), 12(2), 49-55.

Puluhulawa, C. W. (2013). Kecerdasan Emosional dan Kecerdasan Spiritual Meningkatkan Kompetensi Sosial Guru. Makara Human Behavior Studies in Asia, 17(2), 139. https:// doi.org/10.7454/mssh.v17i2.2957

Rahadian, D. (2018). Peran Dan Kedudukan Guru Dalam Masyarakat. Jurnal Petik, 1(1), 26. https://doi.org/10.31980/jpetik.v1i1.56

Ratna Rosita Pangestika, D. (2015). Pendidikan Profesi Guru (Ppg): Strategi Pengembangan Profesionalitas Guru Dan Peningkatan Mutu Pendidikan Indonesia Ratna Rosita Pangestika \& Fitri Alfarisa. Prosiding Seminar Nasional, (1995), 671-683.

Ridho, S. (2014). Pengembangan Karakter Konservasi untuk Mahasiswa Program Pendidikan Profesi Guru Sarjana Mengajar di Daerah Terluar, Terdepan, dan 


\section{MADRASAH}

Jurnal Pendidikan dan Pembelajaran Dasar

p ISSN: 1979-5599 | e ISSN: 2502-194X

P a g e | 153

Tertinggal (PPG-SM3T). Lembaran Ilmu Kependidikan, 43(2), 94-102.

Saat, S. (2014). Guru: Status Dan Kedudukannya Di Sekolah Dan Dalam Masyarakat. Auladuna, 1(1), 102-113.

Sugiharto, M. (2018). Pengaruh Persepsi Mahasiswa Tentang Program PPG Dan Profesi Guru Terhadap Minat Menjadi Guru Pada Mahasiswa Pendidikan Ekonomi Universitas Negeri Yogyakarta (Universitas Negeri Yogyakarta; Vol. 1). https:/ / doi.org/10.1109/ robot.1994.350900

Sutisna, D., Indraswati, D., \& Sobri, M. (2019). Keteladanan Guru sebagai Sarana Penerapan Pendidikan Karakter Siswa. 29-33. https://doi.org/http:/ / dx.doi.org/10.26737/jpdi.v4i2.1236

Werang, B. R. (2010). Pengaruh Keterampilan Manajerial Kepala Sekolah dan Status Sosial Ekonomi Guru Terhadap Kinerja Guru SMA Negeri 1 Merauke Papua. Jurnal Aplikasi Manajemen, 8(2), 421-429.

Widodo, A., Indraswati, D., Erfan, M., Maulyda, M. A., \& Rahmatih, A. I. (2020). Profil minat baca mahasiswa baru PGSD Universitas Mataram. Premiere Educandum: Jurnal Pendidikan Dasar Dan Pembelajaran, 10 (February), 34-48. https:/ / doi.org/10.25273/pe.v10i1.5968

Widodo, A., Husniati, H., Indraswati, D., Rahmatih, A. N., \& Novitasari, S. (2020). Prestasi belajar mahasiswa PGSD pada mata kuliah pengantar pendidikan ditinjau dari segi minat baca. Jurnal Bidang Pendidikan Dasar, 4(1), 26-36. https:/ / doi.org/https:/ / doi.org/10.21067/jbpd.v4i1.3808

Widodo, A., Indraswati, D., \& Sobri, M. (2019). Analisis Nilai-Nilai Kecakapan Abad 21 Dalam Buku. Jurnal Tarbiyah: Jurnal Ilmiah Kependidikan, 8(2), 125-133. https:/ / doi.org/10.18592/tarbiyah.v8i2.3231 